5, 1957. Pp. 36. London: General Electric Co., Ltd., 1957) describes the part to be played by the General Electric Company, Ltd., in the implementation of the British nuclear power programme. The Company is building at Hunterson on the Ayrshire coast one of the world's largest full-scale commercial nuclear power stations, for use by the South of Scotland Electricity Board. Photographs of models of the station and details of its capacity are given in the brochure. The generating capacity will be 360,000 $\mathrm{kW}$., of which $320,000 \mathrm{~kW}$. will be fed into the National Grid system, the remainder being consumed in the station. The two reactors will be loaded initially with 500 tons of uranium. The graphite core of each reactor will consist of about 115,000 graphite blocks and will be enclosed by a spherical steel pressure-shell $70 \mathrm{ft}$. in diameter. In addition to the reactors and the turbine hall, housing six turbo-generator sets with feed water and condensing plant, administration and laboratory blocks and a number of ancillary structures will be built. Between the two reactor structures a pond for the storage of irradiated or spent fuel elements from the reactors, prior to their removal to the processing plant, will be constructed. The first reactor and three turbogenerator sets are scheduled for commissioning in 1961 and the whole station will be fully operational in 1962 .

\section{Milford Haven Conservancy Bill}

ON March 25, during the committee stage in the House of Commons of the Milford Haven Conservancy Bill (see Nature, April 5, p. 937), the amendments moved by Lords Silkin and Ogmore and others were negatived, although Lord Brecon, for the Government, promised to consider further before the report stage the desirability of placing the provision for amenities in a separate section. Some disturbing disclosures were made during the debate. Lord Ogmore revealed that the Chairman of the Pembrokeshire County Council had opposed the suggestion that the whole scheme for development should first be explained to the nation in a. White Paper, and appeared to be concerned solely with local benefits. The Minister of Housing and Local Government had taken a wider view, and had refused the Esso Company permission to develop 1,000 acres, and permission to develop 350 acres had been given only under very stringent conditions. Lord Ogmore pointed out that there were eight developments proposed in the area; besides this proposal for a $£ 20$ million refinery on the north shore, there was the landing stage for the harbour at Popton Point capable of taking the largest tankers afloat; a $£ 9$ million project for two dry docks, five wet-berths and a discharging pier ; a deep-water unloading berth for iron ore; the iron ore stocking ground at Angle or near by ; another refinery on or near the Haven; a group of chemical and kindred factories ; and a ship-repairing project at Pembroke Dock.

These developments, which it wes estimated would bring a further 50,000 people into the area, were likely to have a profound effect on the whole of west Wales and, apart from the effect on the National Park area itself, Lord Ogmore and other speakers were concerned that any essential development should not be allowed to create industrial slums in the way that some nineteenth-century developments had done. His contention that due regard should be had to cultural and social development was strongiy supported by Lord Lloyd and by Lord Hurcomb, who welcomed the writing into the Bill of the powers which the Minister of Power agreed to write into the Electricity Bill. Lord Hurcomb was concerned that planning authorities should not be allowed to give free play at the expense of all other considerations to any profitable industrial or commercial development, and referred to the probable deleterious effect of the proposed dredging on the marine biological station at Dale Fort. As regards oil pollution, he thought that much of the evil could be avoided if the responsible authorities were vigilant and exercised their great powers. The oil companies in Britain had always taken an enlightened attitude.

Lord Brecon, in replying to the debate, said that the Government had very carefully considered the amenity question, and thought that the Bill, as it stood, provided all the care for amenity that will be required in the development of Milford Haven. The Minister of Housing and Local Government and for Welsh Affairs had taken great perconal interest in the question, and could call in all the planning applications for consideration by his Department. The National Parks Commission would be represented on the Board, which would have greater responsibilities for amenities than any other harbour board in Britain. The Government, he seid, is really keen to see that full consideration is given to amenity, and that as little despoliation as possible occurs in the area ; but matters of cultural and social development are the responsibility of the local county council, the committee for further education, youth clubs and other organizations.

\section{Entomologia Experimentalis et Applicato}

WrThIN a year of the first appearance of the new Journal of Insect Physiology, yet another scientific journal dealing with entomology has made its debut. Entomologia Experimentalis et Applicata (1, No. 1; February 1958. Pp. 72. Published quarterly. Annual subscription (for a volume of at least 320 pages) : 32 Dutch guilders; $63 s . ; 8.50$ dollars. Amsterdem : North-Holland Publishing Co., 1958) has a distinguished board of editors drawn from the Netherlands, France, Germany and Great Britain. The first number contains nine papers which formed part of a symposium on "Insect and Foodplant" held at Wageningen in 1957. These interesting papers cover a wide range of topics in insect physiology and biochemistry, ecology, behaviour and plant breeding; but they cannot be regarded as typical of the kind of papers the new journel will carry in the future. The intention is to provide a meeting-ground between experimental and applied entomology. Such problems as the resistance of crop plants to insects, diapause, phenology, biological control and resistance to insecticides are among those which may be expected to figure in future numbers. This journal will certainly serve a most useful purpose. It is well printed and produced on a rather small page measuring 6 in. by $9 \frac{1}{4} \mathrm{in}$.

\section{Worthing Museum}

IN 1956 work commenced on a complete representation of the collections in the Worthing Museum. During its fifty years history, the Museum's collections have undergone a shift of emphasis from natural history and folk material to archæology, a process which has increased rapidly in momentum in the past decade. This might well have been foreseen, since the South Downs near Worthing have been 